\title{
Co nie może się znaleźć w powieści policyjnych procedur (druga notatka dla badaczy i wielbicieli gatunku) ${ }^{* *}$
}

DOI: http://dx.doi.org/10.12775/LC.2021.031

\section{$[\ldots]$}

1. Nie może być tak, żeby bohaterem powieści policyjnych procedur byt prywatny detektyw. Wielki klasyczny detektyw (Dupin, Holmes, Poirot lub panna Marple); strażnik moralności, była guwernantka panna Silver, lub odwrotnie, amator bójek i strzelanek (Spade, Marlowe, Hammer) nie mogą być bohaterami powieści policyjnych procedur. Prawnik Perry Mason lub jakikolwiek inny tutaj też nie pasuje. Bohaterem powieści policyjnych procedur może być krewny lub przyjaciel zabitego pod warunkiem, że pracuje w policji (rzadziej w innym organie władzy), i interesuje się sprawą nie tylko z powodów osobistych, ale i zawodowo, a śledztwo prowadzi, wykorzystując doświadczenie zawodowe i wiedzę.

2. Nie może być tak, że bohater powieści policyjnej jest policjantem, ale nie przestrzega procedur, to znaczy przewidzianego prawem porządku prowadzenia śledztwa: nie zbiera dowodów, nie pisze protokołów itd. Jeśli prowadząc śledztwo bohater-policjant wygłupia się, podszywa pod kogoś innego i łączy dochodzenie w uzdrowiskowej Nicei z przyjemnym spędzaniem czasu jak w filmie Glina czy łajdak z Belmondo - nie jest to powieść policyjnych procedur, ale „śledztwo przygodowe”.

\footnotetext{
* Doktor nauk filologicznych, absolwentka Rosyjskiego Państwowego Uniwersytetu Humanistycznego w Moskwie, autorka publikacji na temat literatury kryminalnej, poetyki dramatu i teorii literatury.

E-mail: nnkirilenko29@gmail.com.

** Przekład na podstawie: Kirilenko, Natalja Natanovna. 2020. Kłassiczeskij detektiw kak żanr kriminalnoj literatury: inwariant i genezis. Moskwa, Jekaterinburg: Kabinietnyj uczonyj: 226-228. Tekst stanowi przekład fragmentu Priłożenije 7. Czego nie możet byt' w policejskom romanie (wtoraja pamiatka dla issledowatielej i lubitielej żanra). Partie opuszczone zostały zaznaczone nawiasami kwadratowymi.
} 
3. Nie może być tak, że bohater powieści policyjnych procedur przestrzega procedur zawsze. W celu zdobycia niezbędnych dla ukarania przestępcy informacji lub, co nie mniej ważne, ze względów humanitarnych, gotów jest je naruszyć. I tak, Kostenko (Pietrowka 38 Juliana Siemionowa) uprzedza matkę nastolatka zamieszanego w napad na kasę oszczędnościową, aby wywiozła go na daczę, by uniknął aresztowania, a sam ma nadzieję wyjednać dlań u wyższych instancji niższy wymiar kary.

4. Nie może być tak, żeby bohater powieści policyjnych procedur prowadzit śledztwo sam, nie uciekając się do pomocy ekspertów tej czy innej specjalności, najczęściej - patologa i fotografa. Jeśli bohater sam jest lekarzem medycyny sądowej (Punkt zapalny Patricii Cornwell, Śmierć $z a$ dnia Kathy Reichs), to powodzenie śledztwa zależy od innego typu ekspertyz.

5. Nie może być tak, żeby bohater powieści policyjnych procedur nie miał ani biografii, ani życia osobistego. Tym różni się on od Wielkiego Detektywa w klasycznym kryminale.

6. Nie może być tak, żeby w powieści policyjnych procedur brakowato obrazu posterunku i miejsca zbrodni, pokazanego z punktu widzenia prowadzacego śledztwo.

7. Nie może być tak, żeby w powieści policyjnych procedur wszystkie postaci mówity tym samym językiem. Śledczy i eksperci używają słownictwa specjalistycznego: „ekspertyza balistyczna”, „wlot pocisku” itp. Przestępcy mówią żargonem. Postaci reprezentujące różne grupy społeczne i różne narodowości mówią inaczej.

8. Nie może się zdarzyć, żeby śledztwo zakończyło się sukcesem tylko dzięki przypadkowi. Bohaterowie powieści policyjnych procedur wiedzą, jak ważne jest, aby im się udało. Jednak równie ważna jest ich profesjonalna wiedza, umysł, dążenie do odkrycia prawdy i inne jakości.

9. Nie może być tak, żeby bohater powieści policyjnych procedur nie miat problemów życiowych. Jeśli bohater podczas śledztwa nie musi pić ani jeść, może nie spać przez kilka dni (i nie cierpieć) - mamy do czynienia z klasycznym kryminałem, „śledztwem przygodowym” lub czarnym kryminałem („hardboiled”).

10. Nie może być tak, żeby $w$ toku śledztwa bohater powieści policyjnych procedur nie miat problemów z przetożonymi czy możnymi tego świata.

11. Nie może być tak, żeby bohater powieści policyjnej zatrzymywat przestępcę bez przeszkód. Przeszkadza mu anomalny upał (Cop Hater i Morderczy upał Eda McBaina), deszcz i sztorm (Maigret i goście z Europy Wschodniej Simenona) czy zaspy śnieżne (Śmierć za dnia Kathy Reichs). Bohater ulega wypadkom (Roseanna Wahlöö i Sjöwall), on lub jego przyjaciel zostaje ranny (w większości utworów) itd. Bohater może nawet zginąć! Patrz: Jean-Christophe Grangé, Purpurowe rzeki.

12. Nie może być tak, żeby w powieści policyjnych procedur śledztwo przychodzito bohaterowi $z$ tatwościa.

Tłum. z rosyjskiego Jelena Kozmina i Anna Skubaczewska-Pniewska 